\title{
The Content of the Corporate Social Responsibility Report on the Company Social and Labor Relations
}

\author{
Natalia Karzaeva ${ }^{1, *}, V^{*}$ yacheslav Kazantsev ${ }^{1}$, Nina Makarova ${ }^{2}$ \\ ${ }^{1}$ Vyatka State University, Kirov, Russia \\ ${ }^{2}$ JSC Baker Tilly Rus, Moscow, Russia \\ *Corresponding author. Email: k-nn@yandex.ru
}

\begin{abstract}
The article presents research materials on testing the hypothesis about the priority of the principles of relevance and comparability when forming the composition of indicators included in the company social accounting. As the basis for the methodology for constructing a system of social accounting indicators, the authors adopted the principles of accounting and substantiated the dominant of the principles of relevance and comparability. The principle of relevance was also used to refine the definition of social accounting, which is presented in the article. The materials of the article also contain the results of the analysis of indicators of social accounting proposed by scientists, specialists and used by companies when preparing it. The illustrated discrepancy between the indicators of the social accounting and the actions of the company when implementing the concept of social responsibility served as the reason for the development of indicators reflecting the measures taken by companies to strengthen social and employment relations with employees. The article presents the indicators proposed by the authors, systematized by groups of relevant actions.
\end{abstract}

Keywords: corporate social responsibility, social accounting, principles, relevance, comparability, indicators.

\section{INTRODUCTION}

Social and employment relations with company employees are central to all regulations governing the procedure for companies to accept social responsibility and accounting [2]. Domestic and foreign scientists, in particular, V.P. Bardovsky, R.V. Dmitriev, S.E. Erypalov, A.D. Zaretsky, M.A. Izmailova, O. Kanaeva, A.E. Kostin, G.B. Kosharnaya, V.V. Krivorotov, V.I. Maslov, E. Rashidin, E.V. Timoshkina, Kim Soojin, Krishna Arunima, Dhanesh Ganga L. Koep, S. Lee, Verčič Tkalac A., Ćorić Sinčić D. and others study the influence of the adoption of corporate social responsibility on the activities of enterprises. Also, problems of the formation of social accounting are not without attention. This topic is the subject of articles by V.O. Bessarabov, M.A. Vakhrushina, V.V. Danshina, E.V. Demyakhina, E.S. Mishacheva, A.A. Tolcheeva, N.V. Rodionova, E.N. Stepanova and others. However, they do not consider the principles of formation of social accounting, which are the methodological basis for constructing the composition of indicators included in the content of the report. In this regard, the main goal of this study was to substantiate the hypothesis about the priority of the principles of relevance and comparability when forming the composition of indicators included in the social accounting of companies.

In accordance with the purpose of the study, the following were identified as the main tasks:

- the analysis of the definitions formulated by scientists and specialists, and explaining the content of the concept of "social accounting";

- comparison of indicators and information included in social accounting with the corresponding actions reflecting the corporate social responsibility of the company;

- development of proposals for improving the system of indicators of the section of the corporate social responsibility report on social and employment relations with company employees.

\section{MATERIALS AND METHODS}

Fundamental provisions of the theory of economic systems serve as the methodological basis of the study. The study is based on a logical analysis of the provisions 
Table 1. Definition of social accounting.

\begin{tabular}{|l|l|}
\hline Definition & Source \\
\hline $\begin{array}{l}\text { a consolidated list and description of all social, sponsorship and charitable projects of } \\
\text { the company }\end{array}$ & $\begin{array}{l}\text { Makarov A.S., } \\
\text { Loginova A.A. [2] }\end{array}$ \\
\hline $\begin{array}{l}\text { a report that largely reveals the social aspect of activities of the organization } \\
\text { (investments in educational programs, health and safety) }\end{array}$ & $\begin{array}{l}\text { Vakhrushina M.A., } \\
\text { Tolchaeva A.A. [3] }\end{array}$ \\
\hline $\begin{array}{l}\text { a set of interrelated quantitative and qualitative indicators reflecting economic, } \\
\text { environmental, social results of interaction between a business entity and society }\end{array}$ & Bessarabov V.O. [4] \\
\hline $\begin{array}{l}\text { a set of data ..., reflecting the environment of existence of the company, principles } \\
\text { and methods of cooperation with influence groups, the results of activities of the } \\
\text { company in the economic, social, environmental spheres of society }\end{array}$ & $\begin{array}{l}\text { Vorobey V.O.,, } \\
\text { Zhurkovskaya I. E. [5] }\end{array}$ \\
\hline
\end{tabular}

of the National Standard of the Russian Federation "Social Responsibility Guidelines" (GOST R ISO 260002012), scientific works in the field of social accounting. Social accounting indicators were formed on the basis of methods of economic and mathematical modeling.

Various methods, including the abstract-logical method, the comparative analysis, the systemic and situational approaches were used in the study.

\section{RESULTS AND DISCUSSION}

The data found in reports should allow the user to get relevant information. This predetermines the need for a clear formulation of the definition of corporate social responsibility report or social accounting. This concept is not defined in the section "Definitions" of the National Standard of the Russian Federation "Social Responsibility Guidelines" (GOST R ISO 26000-2012) [1], however, scientists and specialists give definitions to this concept in their studies. Some of the definitions, which are the most complete, are presented in table 1.

The analysis of the definitions of social accounting (or reports) allows us to conclude that there are two approaches to its content. The first approach, which can be called the project approach, implements the concept of social accounting as information about social projects or company programs. The second approach, which is an effective approach, the authors consider reports as documents that systematize information about the results of activities that affect various spheres of society: economic, environmental and social. The common of the two approaches is the inclusion in the definition of an object - all activities (projects, programs, events, etc.) affecting the interests of stakeholders and allowing the company to be recognized as socially responsible. However, the first approach is limited only to social projects, in contrast to the second approach, which adherents propose to reflect the results of the economic activity.

It should be noted that there is no consensus among experts about the type of information provided. Some authors limit themselves only to indicators [4], but most provide a wide range up to "description" [2].
Based on the generally accepted understanding of the report as a summing up of any kind of activity, the definition of a corporate social responsibility report should also reflect its effective content. In addition, it is extremely important, when drawing up a report, to understand for whom it is being prepared, who will be its reader, user. Knowing the information needs of the user of a corporate social responsibility report will make it meaningful and complete, but not redundant. These two requirements make it possible to formulate the definition of a corporate social responsibility report as a document drawn up by a business entity, reflecting the results of its activities aimed at satisfying the interests of society, for presentation to stakeholders. This definition makes it possible to consider information that reflects the activities, programs and projects carried out by the company in the interests of people, communities and society as a whole, and their results as the subject of a corporate social responsibility report. Consequently, a corporate social responsibility report should contain data and indicators in accordance with the actions recommended by the National Standard of the Russian Federation "Social Responsibility Guidelines" (Table 2). Due to the scale of the research area, this article only deals with the section of social and employment relations with company employees. 
Table 2. Systematization of indicators of the corporate social responsibility report and corresponding actions in the field of social and employment relations.

\begin{tabular}{|c|c|c|c|}
\hline $\begin{array}{l}\text { The } \\
\text { sphere of } \\
\text { problems }\end{array}$ & $\begin{array}{l}\text { Corresponding } \\
\text { actions }\end{array}$ & Accounting indicators & Source \\
\hline \multirow{4}{*}{$\begin{array}{l}\text { Economi } \\
\text { c, social } \\
\text { and } \\
\text { cultural } \\
\text { rights }\end{array}$} & \multirow{4}{*}{$\begin{array}{l}\text { ease of access to } \\
\text { education and } \\
\text { lifelong learning for } \\
\text { members of society }\end{array}$} & $\begin{array}{ll}- & \text { education (thousand rubles / person) } \\
- & \text { growth of competence (thousand rubles) }\end{array}$ & Danshina V.V. [6] \\
\hline & & 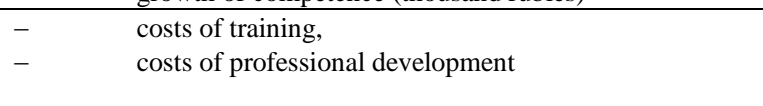 & $\begin{array}{l}\text { Vakhrushina M.A., } \\
\text { Tolcheeva A.A. [3] } \\
\text { Bessarabov V.O. [4] }\end{array}$ \\
\hline & & $\begin{array}{l}\text { - number of employees who have underwent vocational } \\
\text { training, retraining and advanced training }\end{array}$ & $\begin{array}{l}\text { Demyakhina E.V. [7] } \\
\text { Rodionova N.V., } \\
\text { Mishacheva E.S. [8] }\end{array}$ \\
\hline & & $\begin{array}{l}\text { - proportion of company employees who did professional } \\
\text { training during the year }\end{array}$ & Stepanova E.N. [9] \\
\hline \multirow{4}{*}{$\begin{array}{l}\text { Employm } \\
\text { ent and } \\
\text { employm } \\
\text { ent } \\
\text { relations }\end{array}$} & \multirow{4}{*}{$\begin{array}{l}\text { planning the use of } \\
\text { personnel in order to } \\
\text { create permanent } \\
\text { jobs }\end{array}$} & $-\quad$ average headcount of staff & $\begin{array}{l}\text { Vakhrushina M.A., } \\
\text { Tolcheeva A.A. [3] }\end{array}$ \\
\hline & & job growth rate & Danshina V.V. [6] \\
\hline & & personnel turnover rate & $\begin{array}{l}\text { Demyakhina E.V. [7], } \\
\text { Rodionova N.V., } \\
\text { Mishacheva E.S. [8] }\end{array}$ \\
\hline & & job preservation rate & Demyakhina E.V. [7] \\
\hline \multirow{19}{*}{$\begin{array}{l}\text { Working } \\
\text { condition } \\
\mathrm{s} \quad \text { and } \\
\text { social } \\
\text { protectio } \\
\text { n }\end{array}$} & \multirow{8}{*}{$\begin{array}{l}\text { - ensure the } \\
\text { compliance of } \\
\text { working conditions } \\
\text { with the } \\
\text { requirements of laws } \\
\text { and regulations; } \\
\text { - provide decent } \\
\text { working conditions } \\
\text { in terms of } \\
\text { remuneration, } \\
\text { - provide wages and } \\
\text { other forms of } \\
\text { remuneration in } \\
\text { accordance with } \\
\text { laws, regulations or } \\
\text { collective } \\
\text { agreements }\end{array}$} & costs of payment of basic wages & Danshina V.V. [6] \\
\hline & & payroll budget & $\begin{array}{l}\text { Vakhrushina M.A., } \\
\text { A.A. Tolcheeva [3] }\end{array}$ \\
\hline & & average monthly wages of employees of the enterprise & $\begin{array}{l}\text { Vakhrushina M.A., } \\
\text { Tolcheeva A.A. [3] } \\
\text { Demyakhina E.V. [7] }\end{array}$ \\
\hline & & - $\quad$ minimum wage of the company employees & Demyakhina E.V. [7] \\
\hline & & $\begin{array}{l}\begin{array}{l}\text { coefficient of differentiation of wages in the } \\
\text { organization }\end{array} \\
\end{array}$ & Demyakhina E.V. [7] \\
\hline & & - $\quad$ payment and adjustment of wages & Demyakhina E.V. [7] \\
\hline & & $-\quad$ pay rise (person) & Danshina V.V. [6] \\
\hline & & $\begin{array}{l}\text { - ratio of the average salary in the company to the average } \\
\text { salary in the region }\end{array}$ & $\begin{array}{l}\text { Danshina V.V. [6] Rodionova } \\
\text { N.V., } \\
\text { Mishacheva E.S. [8] }\end{array}$ \\
\hline & \multirow{7}{*}{$\begin{array}{l}\text { fulfill all obligations } \\
\text { to provide social } \\
\text { protection to } \\
\text { workers; }\end{array}$} & - $\quad$ costs of social and pension insurance & Danshina V.V. [6] \\
\hline & & $\begin{array}{l}\text { improvement, housing and public utilities (thousand } \\
\text { rubles/person) }\end{array}$ & Danshina V.V. [6] \\
\hline & & $-\quad$ social assistance (person, thousand rubles) & $\begin{array}{l}\text { Vakhrushina M.A., } \\
\text { Tolcheeva A.A. [3] Danshina } \\
\text { V.V. [6], } \\
\text { Rodionova N.V., } \\
\text { Mishacheva E.S. [8] }\end{array}$ \\
\hline & & charity expenses & $\begin{array}{l}\text { Vakhrushina M.A., } \\
\text { Tolcheeva A.A. [3] }\end{array}$ \\
\hline & & $-\quad$ costs of social support of society, including charity & Demyakhina E.V. [7] \\
\hline & & $\begin{array}{l}-\quad \begin{array}{l}\text { index of specific social investments } \\
\text { rubles/person) }\end{array} \\
\end{array}$ & Stepanova E.N. [9] \\
\hline & & $\begin{array}{l}- \\
\text { profit }\end{array}$ & Stepanova E.N. [9]] \\
\hline & \multirow{4}{*}{$\begin{array}{l}\text { - develop, } \\
\text { implement and } \\
\text { maintain a policy in } \\
\text { the field of labor } \\
\text { protection } \\
\text { - analyze and } \\
\text { control the risks } \\
\text { associated with } \\
\text { labor protection and } \\
\text { caused by the } \\
\text { activities of the } \\
\text { organization; } \\
\text { - require compliance } \\
\text { with appropriate } \\
\text { procedures in } \\
\text { ensuring labor } \\
\text { protection }\end{array}$} & - $\quad$ occupational injury rate per worked hours & Stepanova E.N. [9] \\
\hline & & $-\quad$ proportion of victims of industrial accidents $(\%)$ & Demyakhina E.V. [7] \\
\hline & & $\begin{array}{l}\text { proportion of employees who were diagnosed with } \\
\text { occupational diseases }\end{array}$ & Demyakhina E.V. [7] \\
\hline & & $\begin{array}{l}\text { number of violations in the field of industrial safety and } \\
\text { environmental protection identified by regulatory authorities during } \\
\text { the year (Rostekhnadzor (Federal Service for Environmental, } \\
\text { Technological and Nuclear Oversight of Russia), Rostrud (Federal } \\
\text { Labor and Employment Service), Rosprirodnadzor (Federal Service } \\
\text { for Supervision of Natural Resource Usage), Rospotrebnadzor } \\
\text { (Federal Service for the Oversight of Consumer Protection and } \\
\text { Welfare), State Fire Supervision, Glavgosexpertiza (General Board } \\
\text { of State Expert Review), etc.) }\end{array}$ & Demyakhina E.V. [7] \\
\hline
\end{tabular}


Table 2. Continued.

\begin{tabular}{|c|c|c|c|}
\hline $\begin{array}{l}\text { The sphere } \\
\text { of problems }\end{array}$ & Corresponding actions & Accounting indicators & Source \\
\hline \multirow[t]{5}{*}{$\begin{array}{l}\text { On-the-job } \\
\text { safety }\end{array}$} & $\begin{array}{l}\text { provide safety equipment, } \\
\text { including personal protective } \\
\text { equipment, necessary to } \\
\text { prevent occupational injuries, } \\
\text { illnesses and accidents, as well } \\
\text { as to act in case of emergency } \\
\text { situations }\end{array}$ & $\begin{array}{l}-\quad \text { costs of labor protection, ensuring } \\
\text { industrial safety (thousand rubles/person) }\end{array}$ & $\begin{array}{l}\text { Vakhrushina M.A., } \\
\text { Tolcheeva A.A. [3] Danshina } \\
\text { V.V. [6], } \\
\text { Stepanova } \quad \text { E.N. } \\
\text { Bessarabov V.O. [4] } \\
\text { Demyakhina E.V. [7] }\end{array}$ \\
\hline & \multirow{4}{*}{$\begin{array}{l}\text { - develop, implement and } \\
\text { maintain a policy in the field of } \\
\text { labor protection } \\
\text { - analyze and control the risks } \\
\text { associated with labor protection } \\
\text { and caused by the activities of } \\
\text { the organization; } \\
\text { - require compliance with } \\
\text { appropriate procedures in } \\
\text { ensuring labor protection }\end{array}$} & - $\quad$ occupational injury rate per worked hours & Stepanova E.N. [9] \\
\hline & & $\begin{array}{lllll}- & \text { proportion of victims of industrial } \\
\text { accidents }(\%) & & & & \\
\end{array}$ & Demyakhina E.V. [7] \\
\hline & & $\begin{array}{l}\text { proportion of employees who were } \\
\text { diagnosed with occupational diseases }\end{array}$ & Demyakhina E.V. [7] \\
\hline & & $\begin{array}{l}\text { number of violations in the field of } \\
\text { industrial safety and environmental protection } \\
\text { identified by regulatory authorities during the year } \\
\text { (Rostekhnadzor (Federal Service for Environmental, } \\
\text { Technological and Nuclear Oversight of Russia), } \\
\text { Rostrud (Federal Labor and Employment Service), } \\
\text { Rosprirodnadzor (Federal Service for Supervision of } \\
\text { Natural Resource Usage), Rospotrebnadzor (Federal } \\
\text { Service for the Oversight of Consumer Protection and } \\
\text { Welfare), State Fire Supervision, Glavgosexpertiza } \\
\text { (General Board of State Expert Review), etc.) }\end{array}$ & Demyakhina E.V. [7] \\
\hline \multirow[t]{2}{*}{$\begin{array}{l}\text { Human } \\
\text { developme } \\
\text { nt and on- } \\
\text { the-job } \\
\text { training }\end{array}$} & $\begin{array}{l}\text { provide employees with access } \\
\text { to skills development, training, } \\
\text { apprenticeships, and career } \\
\text { opportunities on the equal and } \\
\text { non-discriminatory basis }\end{array}$ & $\begin{array}{l}\text { See the section "Economic, Social and Cultural } \\
\text { Rights" }\end{array}$ & \\
\hline & $\begin{array}{l}\text { create programs that promote } \\
\text { health and well-being }\end{array}$ & $\begin{array}{ll}- & \text { culture and art } \\
- & \text { здравоохранение } \\
- & \text { religious denominations } \\
- & \text { sports, healthy lifestyle }\end{array}$ & Danshina V.V. [6], \\
\hline
\end{tabular}

The analysis of the correspondence between the indicators of the corporate social responsibility report and actions in the field of social and employment relations, which make it possible to recognize the company as socially responsible, shows the presence of whole blocks of problem areas that are not presented in corporate social responsibility reports, in particular, the basic principles and rights in the world of work. As for the block of hiring and employment relations the authors propose indicators that indirectly characterize only the planning of the use of personnel in order to create permanent jobs. For the rest of the actions of this block, the authors do not offer any indicators. More than half of the corresponding actions in the area of "Working conditions and social protection" are not reflected in the report indicators (the corresponding actions that were not reflected in the indicators are presented in Table 3 ). In addition, it should be noted that some of the indicators reflect the results of actions in the direction of social responsibility, for example, the number of employees who underwent vocational training, retraining or advanced training, as well as the company costs associated with these programs, while others reflect negative processes, threats to personnel security, for example, the proportion of victims of industrial accidents or who were diagnosed with occupational diseases. According to the authors of the article, the indicators should reflect the results of measures to ensure occupational safety. In this particular case, it is advisable to show the dynamics of reducing the number of victims of accidents or the sick as a result of the implementation of the measures.

The methodological basis of the process of constructing the indicators of the corporate social responsibility report should be the principles [10-14]. Earlier, we substantiated the dominant in the system of principles of relevance and compliance. The indicators characterizing the company's activities in the area of social responsibility should satisfy the interests of users of the corporate social responsibility report, on the one hand, and, on the other hand, reflect the results of this activity, specific projects, programs and activities. Without claiming to be complete, additional indicators proposed by the authors of this article for inclusion in the corporate social responsibility report by groups of relevant actions are presented in Table 3.

\section{CONCLUSION}

Acceptance and implementation of corporate social responsibility by a company presupposes drawing up a corporate social responsibility report. Its content is the subject of research by many scientists and specialists. 
The analysis of the results of these studies allowed us to draw a number of conclusions:

- the number of indicators characterizing the social and employment relations of the company with the employee is very limited;
- many areas of the social activity are not reflected in the indicators recommended by specialists and actually used by companies;

- some indicators reflect not the results of the social activities of companies, but the existing threats to personnel security.

Table 3. Proposed indicators of the corporate social responsibility report by groups of relevant actions in the field of social and labor relations

\begin{tabular}{|c|c|c|}
\hline $\begin{array}{l}\text { The sphere of } \\
\text { problems }\end{array}$ & Corresponding actions & Accounting indicators \\
\hline \multirow[t]{2}{*}{$\begin{array}{l}\text { Fundamental } \\
\text { principles and } \\
\text { rights at work }\end{array}$} & $\begin{array}{l}\text { - regular assess the impact of company policies } \\
\text { and activities on promoting equal opportunities } \\
\text { and non-discrimination; } \\
\text { - organize or participate in programs that promote } \\
\text { employment of young and older workers, } \\
\text { provision of equal employment conditions for } \\
\text { women, a more balanced representation of } \\
\text { women in high positions }\end{array}$ & $\begin{array}{l}\text { - proportion of women who hold } \\
\text { executive positions; } \\
\text { - proportion of foreign persons in the } \\
\text { nominal roll; } \\
\text { - proportion of pensioners in the nominal } \\
\text { rol; } \\
\text { - number of hired citizens under the age of } \\
25 \text {; } \\
\text { - number of hired citizens at the age of } \\
\text { retirement }\end{array}$ \\
\hline & $\begin{array}{l}\text { organize workplaces for people with health } \\
\text { limitations }\end{array}$ & $\begin{array}{l}\text { - an increase in jobs for people with health } \\
\text { limitations }\end{array}$ \\
\hline \multirow{5}{*}{$\begin{array}{l}\text { Employment and } \\
\text { employment } \\
\text { relations }\end{array}$} & $\begin{array}{l}\text { control over the legal registration of actual labor } \\
\text { relations }\end{array}$ & $\begin{array}{l}\text { - dynamics of the number of violations } \\
\text { during the execution of labor contracts }\end{array}$ \\
\hline & $\begin{array}{l}\text { measures to reduce economic and social } \\
\text { consequences of closing of an enterprise }\end{array}$ & $\begin{array}{l}\text { - costs of carrying out measures to reduce } \\
\text { economic and social consequences of } \\
\text { closing of an enterprise }\end{array}$ \\
\hline & $\begin{array}{l}\text { measures to prevent direct or indirect } \\
\text { discrimination }\end{array}$ & $\begin{array}{l}\text { - costs of carrying out measures to prevent } \\
\text { direct or indirect discrimination; } \\
\text { - number of cases of prevention of direct } \\
\text { or indirect discrimination }\end{array}$ \\
\hline & $\begin{array}{l}\text { not to dismiss employees unreasonably or on } \\
\text { discriminatory grounds }\end{array}$ & $\begin{array}{l}\text { - dynamics of documented cases of } \\
\text { dismissal of employees unreasonably or } \\
\text { on discriminatory grounds }\end{array}$ \\
\hline & $\begin{array}{l}\text { protect personal data and confidentiality of } \\
\text { workers }\end{array}$ & $\begin{array}{l}\text { - proportion of cases of prevention of } \\
\text { personal data breach and confidentiality of } \\
\text { workers in their total number }\end{array}$ \\
\hline \multirow[t]{3}{*}{$\begin{array}{l}\text { Working } \\
\text { conditions and } \\
\text { social protection }\end{array}$} & $\begin{array}{l}\text { - ensure the compliance of working conditions } \\
\text { with the requirements of laws and regulations; } \\
\text { - provide decent working conditions: working } \\
\text { hours, days off, vacations, maternity protection } \\
\text { and the opportunity to combine work with family } \\
\text { responsibilities }\end{array}$ & $\begin{array}{l}\text { - dynamics of the number of cases of } \\
\text { violation of working conditions (including } \\
\text { the provision of days off, holidays, etc.) to } \\
\text { the requirements of laws and regulations; } \\
\text { - number of cases of combining work with } \\
\text { family circumstances }\end{array}$ \\
\hline & $\begin{array}{l}\text { if possible, allow keeping up national or religious } \\
\text { traditions and customs }\end{array}$ & $\begin{array}{l}\text { - number of cases of permission to keep } \\
\text { up national or religious traditions and } \\
\text { customs }\end{array}$ \\
\hline & $\begin{array}{l}\text { pay overtime as required by law, regulation or } \\
\text { collective agreement }\end{array}$ & $\begin{array}{l}\text { - dynamics of the propotion of overtime } \\
\text { hours in the total working time; } \\
\text { - dynamics of the number of cases of } \\
\text { violation of laws, regulations or collective } \\
\text { agreements on overtime pay }\end{array}$ \\
\hline \multirow[t]{2}{*}{ On-the-job safety } & $\begin{array}{l}\text { document and investigate all occupational health } \\
\text { and safety incidents and problems with the } \\
\text { purpose of minimizing or eliminating them }\end{array}$ & $\begin{array}{l}\text { - the number of incidents related to } \\
\text { occupational safety; } \\
\text { - динамика количества инцидентов, } \\
\text { связанных с охраной труда }\end{array}$ \\
\hline & $\begin{array}{l}\text { eliminate psychosocial risks in the workplace that } \\
\text { contribute to or lead to stress and illness }\end{array}$ & $\begin{array}{l}\text { - costs of activities to strengthen the } \\
\text { psychosocial state of the employee and } \\
\text { the team as a whole }\end{array}$ \\
\hline $\begin{array}{l}\text { Human } \\
\text { development }\end{array}$ & $\begin{array}{l}\text { provide, if necessary, assistance to dismissed } \\
\text { workers in applying for a new job, training }\end{array}$ & $\begin{array}{l}\text { - number of cases of employment of } \\
\text { dismissed employees with the company } \\
\text { help }\end{array}$ \\
\hline
\end{tabular}


This circumstance predetermines the need, on the basis of reporting principles, such as relevance and compliance, to form a system of indicators for the corporate social responsibility report (Table 3). These indicators reflect the results of the company's social activities and are relevant to the information expectations of stakeholders.

\section{REFERENCES}

[1] Social Responsibility Guidelines National Standard of the Russian Federation GOST R ISO 260002012, https://docs.cntd.ru/document/1200097847.

[2] A. S. Makarov, A. A. Loginova, Corporate social responsibility, non-financial reporting and development of methods for analyzing socially responsible investments of a company, in: Accounting. Analysis. Control, 3(39) (2017) pp. 146-157.

[3] M. A. Vakhrushina, A. A. Tolchaeva, Corporate reporting as a result of the evolution of company reporting information Bulletin of Perm University, 12(2) (2017) pp. 297-310.

[4] V. O. Bessarabov, The relationship of financial and social reporting indicators as the basis for the development of social responsibility of business, in: Economy: yesterday, today, tomorrow, 7(12A) (2017) pp. 15-27

[5] V. O. Vorobey, I. E. Zhurkovskaya, Non-financial reporting: a tool for a socially responsible enterprise, in: Kiev, UN Office in Ukraine, 2010, pp. 84.

[6] V. V. Danshina, Some approaches to assessing the effectiveness of innovative strategies of socially responsible enterprises, in: Economic strategies, 2 (2018) pp. 228-235.

[7] E. V. Demyakhina, Planning indicators of corporate social responsibility, in: Organizational-economic and innovative-technological problems of modernization of the Russian economy. Collection of articles of the VIII International Scientific and Practical Conference, 2018, pp. 43-47.

[8] N. V. Rodionova, E.S. Mishacheva, Formation of the Institute of Public Non-Financial Reporting in Russia, in: Bulletin of the Vladimir State University named after Alexander Grigorievich and Nikolai Grigorievich Stolypin, 1(27) (2021) pp. 71-88.

[9] E. N. Stepanova, The analysis of corporate social responsibility based on non-financial reporting (on the example of the Murmansk region), in: The North and the Market: Formation of the Economic Order, 4(55) (2017) pp.69-79
[10] E. V. Karanina, D. Loginov, Indicators of Economic Security of the Region: a Risk-Based Approach tu Assessing and Rating, in: IOP Conference Series: Materials Science and Engineering, 90(1) (2017) pp. 012087

[11] E. V. Karanina, O. A. Ryazanova, A. N. Timin, L. P. Domracheva, Diagnostigs and Monitoring of Economic entities Security, in: E3S Web of Conferences. 2018 Topical Problems of Architecture, Civil Engineering and Environmental Economics, TPACEE 2018, pp. 08002.

[12] N. N. Karzaeva, Methodological aspects of building a system of indicators of personnel security of an economic entity, in: Bulletin of the Academy, 2 (2019) pp. 62-74.

[13] N. N. Karzaeva, L. V. Davydova, Methodological Approaches for Creating a System of Securiti Indicators for Company's Personnel, in: Utopía y Praxis Latinoamericana, 25(Extra 6) (2020) pp. 219228.

[14] R. Wang, Y. Huang, Communicating corporate social responsibility (CSR) on social media, in: Corporate Communications: An International Journal, 23(3) (2018) pp. 326-341. 